\title{
Ontogeny of Insulin-Like Growth Factor-Binding Protein-1, -2, and -3: Quantitative Measurements by Radioimmunoassay in Human Fetal Serum
}

\author{
PETER BANG, MAGNUS WESTGREN, ${ }^{1}$ JÜRG SCHWANDER, WERNER F. BLUM, \\ RON G. ROSENFELD, AND MAGNUS STANGENBERG ${ }^{1}$ \\ Department of Endocrinology, Karolinska Hospital [P.B.] and Department of Obstetrics and \\ Gynecology, Huddinge University Hospital [M.W., M.S.], Karolinska Institute, Stockholm, \\ Sweden; Department of Pediatrics, Division of Endocrinology, Stanford University School of \\ Medicine, Stanford, California 94305 [P.B., R.G.R.]; Department of Internal Medicine, \\ Kantonspital, Basel, Switzerland [J.S.]; and Department of Paediatrics, Eberhard-Karls \\ University, Tübingen, Germany /W.F.B./
}

\section{ABSTRACT}

There is evidence for a role for IGF-I in the endocrine control of human fetal growth despite the low serum IGF-I concentrations. The formation in serum of binary complexes between IGF-I or -II and either of six IGF binding proteins (IGFBP-1 to -6) and, in particular, of long-lived ternary complexes between IGF-I or -II, IGFBP-3, and acid-labile subunit is thought to regulate IGF-I bioavailability by increasing its serum half-life. The present study assesses the bioavailability of circulating IGF-I in 19- to 35-wk gestation human fetuses in utero 1) by quantitative RIA measurements of IGF and IGFBP in serum and 2) by examining whether serum proteolysis of IGFBP-3 may further increase IGF-I bioavailability. Fetal serum concentrations of IGFBP-3, IGF-I, and IGF-II were low with marked or only modest increases with gestational age $(p<$ $0.001, p<0.005$, and $p<0.05$, respectively). The mean molar ratio between IGF-I plus -II and IGFBP-3 demonstrated a molar excess of IGF $(50 \%)$ similar to that in adolescents but in contrast to the 1:1 molar ratio in adults. The median IGFBP-2 concentration was 3 -fold elevated to a molar concentration similar to that of IGFBP-3 (adult serum displays 10 -fold higher IGFBP-3 concentrations).

IGF-I and IGF-II are important paracrine/autocrine fetal growth factors with potential actions as early as during human embryogenesis (1-5). In addition, IGF-I may be an important endocrine growth factor regulating generalized

Received December 20, 1993; accepted April 6, 1994.

Correspondence and reprint requests: Peter Bang, M.D., Ph.D., Department of Endocrinology, Karolinska Hospital, 10401 Stockholm, Sweden.

Supported by grants from the Swedish Medical Research council (4224 and Research Fellowship 1061/91), Novo-Nordisk (Nordisk grant for the study of growth), and Grant HD28703 from the National Institutes of Health (R.G.R.).

'Previously appointed to King Faisal Specialist Hospital, Riyadh, Saudi Arabia.
The median serum IGFBP-1 concentration was not elevated as previously reported in newborns. IGFBP-3 protease activity was not increased in fetal serum, in contrast to pregnancy serum and amniotic fluid. Nevertheless, IGFBP-3 protease activity did interfere with IGFBP-3 determinations by Western ligand blotting, and IGFBP-1 and IGFBP-2 levels obtained by this technique did not correlate with concentrations determined by RIA, stressing the importance of quantitative IGFBP measurements. In summary, increased IGF-I bioavailability in the human fetus is suggested by the molar excess of IGF over IGFBP-3 and the increase in IGFBP-2, which do not form a long-lived ternary complex. The lack of suppression of fetal serum IGFBP-1 may suggest that the delivery of IGF-I to the tissues is normal. (Pediatr Res 36: 528-536, 1994)

\author{
Abbreviations \\ ALS, acid-labile subunit \\ IGFBP, IGF binding protein \\ IUGR, intrauterine growth retarded \\ TBS, Tris-buffered saline \\ AU, absorbance unit
}

fetal growth later in gestation. Although fetal serum IGF-I concentrations are low, they correlate with fetal weight or bone length measures of 15- to 37-wk gestation human fetuses in utero $(6,7)$. In newborn cord serum, IGF-I concentration correlates with birth weight, and serum IGF-I concentrations are decreased in preterm and IUGR newborns (8-12). In contrast, serum IGF-II levels do not correlate with fetal weight or length $(6,7,11)$.

Six IGFBP have been characterized (13) and demonstrated to be widely expressed in human fetal tissues (14-16). The IGFBP are thought to modulate IGF actions 
at the cellular level by regulating IGF binding to the type 1 IGF receptor. In addition, IGFBP regulate the bioavailability of circulating IGF by increasing IGF half-life (17) and by modulating IGF capillary transport and tissue distribution $(18,19)$. In adult human serum, IGF are predominantly bound with high affinity to IGFBP-3, which subsequently associates with an ALS to form a 150-kD ternary complex (20). IGF are more bioavailable when bound in the 44-kD binary complex to any of the other IGFBP, which do not associate with ALS (17). Proteolysis of IGFBP-3, demonstrated in term pregnancy serum and amniotic fluid (21-23), may offer an additional mechanism for regulation of IGF availability, presumably by altering binary and ternary complex formation. However, the source of pregnancy IGFBP-3 protease and whether it affects the fetal compartment are not known. IGFBP-2 and IGFBP-3 levels in fetal and newborn serum have been previously determined by Western ligand blotting. This technique, however, is semiquantitative at best and may be further invalidated by the presence of proteolytic IGFBP fragments $(23,24)$. Specific transcapillary transport of IGFBP-1 in response to insulin makes this IGFBP particularly interesting as a carrier of IGF-I (18, 19). IGFBP-1 concentrations are elevated in newborn serum (25-27), suggesting that IGFBP-1 accumulates and IGF-I transport may be decreased. However, it is unknown whether serum IGFBP-1 levels are also elevated in the human fetus in utero.

In the present study, fetal serum concentrations of IGF-I and IGF-II were measured by RIA after acid chromatography. To assess IGF availability, serum IGFBP-1, -2 , and -3 levels in the human fetus in utero were measured by Western ligand blotting as well as by RIA to determine the relative quantities of IGFBP. Furthermore, IGFBP-3 proteolysis, which may have additional impact on fetal IGF availability, was assessed.

\section{METHODS}

\section{Subjects}

The study included 34 human fetuses who had undergone cordocentesis due to rhesus isoimmunization of the mothers. Cordocentesis was performed according to the original technique described by Daffos et al. (28) if maternal antibody titers were higher than 1:32 or if the obstetric history included perinatal mortality or severe morbidity. Kleihauer-Betke stain was performed on all specimens, and only those that contained $100 \%$ fetal blood were included in the study. Of the 34 fetuses, nine were designated as not affected after typing of fetal blood. All blood samples were kept on ice until centrifuged. Plasma and serum were stored at $-20^{\circ} \mathrm{C}$ until analyzed. Hematologic indices were analyzed in EDTA plasma using an automatic analyzer (Coulter Counter 5 Plus 3, Coulter Electronics, Hialeah, FL). The quantity of serum obtained from each fetus was limited, and in some cases not all analyses could be completed. The study had departmental ethical approval from the King Faisal Specialist Hospital, where the re- search program of rhesus isoimmunization of mothers was carried out, and informed written consent was obtained from the pregnant women.

\section{Materials}

Recombinant human IGF-I, IGF-II, des(1-3)IGF-I, and IGFBP-1 were gifts from KabiGen (Kabi-Pharmacia, Stockholm, Sweden), and these peptides were iodinated as previously described (30). Recombinant human glycosylated and nonglycosylated IGFBP-3 were kindly donated by Celtrix (Santa Clara, CA) and nonglycosylated IGFBP-3 was iodinated as previously described (29).

\section{RIA}

IGF-I and IGF-II. Serum concentrations of IGF-I and IGF-II were determined by RIA after acid gel filtration to exclude interference of IGFBP (30). Des(1-3)IGF-I, which has reduced affinity for IGFBP, was used as radioligand in the IGF-I RIA. The recovery of unlabeled IGF-I was $95 \%$ and the intra- and interassay coefficients of variation were 5 and $11 \%$, respectively. The lowest detectable quantity of IGF-I was $0.02 \mathrm{ng} /$ tube. Crossreactivity with insulin was less than $0.1 \%$ and with IGF-II less than $2 \%$. In the IGF-II RIA, the least detectable quantity was $0.05 \mathrm{ng} /$ tube. The intra- and interassay coefficients of variation were 4 and $12 \%$, respectively. Cross-reactivity with IGF-I was less than $2 \%$ and with insulin less than $0.1 \%$.

IGFBP-1. Serum IGFBP-1 concentrations were determined by RIA as described by Póvoa et al. (31). The intra- and interassay coefficients of variation were 3 and $11 \%$, respectively, and the detection limit was $3.0 \mu \mathrm{g} / \mathrm{L}$. Cross-reactivity with IGFBP-2 and IGFBP-3 was less than 0.5 and $0.05 \%$, respectively.

IGFBP-2. Serum IGFBP-2 concentrations were determined by an RIA recently described by Schwander and Mary (32). Human recombinant IGFBP-2 produced in Chinese hamster ovary cells was used as a reference preparation and as an immunogen to raise antibodies in rabbits. The sensitivity was $0.2-0.5 \mathrm{ng} /$ tube and the cross-reactivity with IGFBP-1 and IGFBP-3 was less than 1 and $0.01 \%$, respectively. The intra- and interassay coefficients of variation were 6 and $12 \%$, respectively.

IGFBP-3. IGFBP-3 concentrations were determined in serum by RIA as described earlier (33). The intra- and interassay coefficients of variation were 3.5 and $7.3 \%$, respectively, and the detection limit was $0.03 \mathrm{ng} /$ tube. Cross-reactivity with IGFBP-1 and IGFBP-2 was less than $0.05 \%$ for each.

\section{Western Ligand Blot Analysis}

Analysis of IGFBP in fetal serum by Western ligand blotting was performed as originally described by Hossenlopp et al. (34) with minor modifications. Briefly, serum $(2.5 \mu \mathrm{L})$ was diluted with nonreducing SDS sample buffer (0.5 M Tris, pH 6.8; $69 \%$ glycerol; $4 \%$ SDS) and 
processed by SDS-PAGE (10\% or $12 \%$ gels) at $45 \mathrm{~V}$ overnight. Prestained molecular weight standards were diluted in SDS sample buffer containing $1 \mathrm{mM}$ DTT and processed in parallel. Separated proteins were electroblotted onto nitrocellulose filters $(0.45-\mu \mathrm{m}$ pore size $)$ in a Hoefer Semi-dry Transphor unit (Hoefer Scientific Instruments, San Francisco, CA) at $200 \mathrm{~mA}$. Filters were treated with $3 \% \mathrm{NP} 40$ in TBS $(0.1 \mathrm{M}$ Tris, $0.15 \mathrm{M} \mathrm{NaCl}$, $\mathrm{pH} 7.4$ ) for $20 \mathrm{~min}$, and blocked with $1 \%$ BSA in TBS for $120 \mathrm{~min}$ at $20^{\circ} \mathrm{C}$. Filters were probed with ${ }^{125}$ I-labeled IGF-II or a mixture of ${ }^{125}$ I-labeled IGF-I and IGF-II in TBS containing $1 \%$ BSA $\left(2 \times 10^{6} \mathrm{cpm} / 25 \mathrm{~mL}\right)$ overnight at $4^{\circ} \mathrm{C}$. Thereafter, filters were washed with $0.1 \%$ Tween 20 in TBS for $1 \times 20 \mathrm{~min}$ and $1 \times 120 \mathrm{~min}$. Nitrocellulose filters were dried and visualized by autoradiography. Autoradiography films were quantified by densitometry using an UltraScan densitometer (LKB Instruments, Inc., Gaithersburg, MD). Densitometry values were corrected for interassay variability by comparison with three internal reference sera.

Western ligand blot IGFBP bands were identified by processing recombinant human IGFBP in parallel $(50 \mathrm{ng}$ of IGFBP-1, $50 \mathrm{ng}$ of IGFBP-2 (32), or $50 \mathrm{ng}$ of glycosylated IGFBP-3; data not shown) or by prior immunoprecipitation with specific IGFBP antibodies as previously described (35), with minor modifications. Briefly, $5 \mu \mathrm{L}$ of fetal serum and $5 \mu \mathrm{L}$ of the undiluted antiserum $(\alpha$-HEC for IGFBP-2 (35) or $\alpha$-IGFBP-3-g1 for IGFBP-3 (23) were mixed with $40 \mu \mathrm{L}$ of SAC 1 buffer $(0.01 \mathrm{M}$ Tris, $0.15 \mathrm{M}$ sodium chloride, $0.5 \% \mathrm{NP} 40, \mathrm{pH} 8.0$ ) and incubated overnight at $4^{\circ} \mathrm{C}$. The IGFBP-antibody complexes were precipitated after the addition of $50 \mu \mathrm{L}$ of Pansorbin (Calbiochem, San Diego, CA) washed in SAC 1 buffer and incubation for $2 \mathrm{~h}$ at $20^{\circ} \mathrm{C}$. The pellet was washed three times and, after the addition of nonreducing SDS sample buffer, the pellet was boiled for $5 \mathrm{~min}$. The supernatant was processed by Western ligand blotting as described below.

\section{IGFBP-3 Protease Assay}

Fetal serum was assessed for proteolytic activity capable of degrading radiolabeled IGFBP-3 according to the method of Lamson et al. (29). Briefly, $2 \mu \mathrm{L}$ of serum were incubated with $30000 \mathrm{cpm}$ of ${ }^{125}$ I-labeled IGFBP-3 (nonglycosylated) in a total volume of $50 \mu \mathrm{L}$ of $0.1 \mathrm{M}$ Tris for $5 \mathrm{~h}$ at $37^{\circ} \mathrm{C}$. After addition of nonreducing SDS sample buffer, the samples were processed by SDS-PAGE (15\% gels) as described under Western ligand blot analysis. After electrophoresis, the SDSpolyacrylamide gel was dried in a gel dryer and exposed to $\mathrm{x}$-ray film at $-70^{\circ} \mathrm{C}$ overnight. Films were evaluated by laser densitometry (LKB Instruments, Inc.). Protease activity was defined as the absorbance of the sum of fragments of ${ }^{125}$ I-labeled IGFBP-3 with molecular mass lower than $30 \mathrm{kD}$ (intact labeled peptide) relative to the total density in the lane. To correct for interassay variability, the quantity of proteolysis was expressed as a percentage of the protease activity observed with a control serum pool from healthy adults, which was given an arbitrary value of $100 \%$.

\section{Statistics}

Values are presented as median and range, if not otherwise stated. IGF-I and IGF-II concentrations, which conformed to a log-normal distribution, were log transformed before regression analysis. Linear regression and multiple regression analyses were performed using a computer program (SOLO, BMDP Statistical Software, Inc., Los Angeles, CA).

\section{RESULTS}

The median gestational age of the human fetuses at the time of blood sampling was $28 \mathrm{wk}$ (range, 19-35 wk). The median $\mathrm{Hb}$ concentration of all fetuses was $88 \mathrm{~g} / \mathrm{L}$ (range, $28-141 \mathrm{~g} / \mathrm{L}$ ). The percentage of the normal median $\mathrm{Hb}$ value for that particular week of gestation according to Rodech and Nicolini (36) was $75 \%$ (range, 21-105\%). In the group of affected fetuses, the median $\mathrm{Hb}$ concentration was $71 \mathrm{~g} / \mathrm{L}(28-135 \mathrm{~g} / \mathrm{L})$ or $53 \%(21-102 \%)$ of control values. Estimates of fetal size in utero were complicated by fetal edema in affected fetuses and complete data were not available. The median infant birth

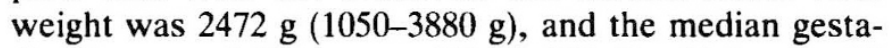
tional age at delivery was $37 \mathrm{wk}(27-41 \mathrm{wk})$ for the 25 affected fetuses, which were all delivered at King Faisal Specialist Hospital. All infant sizes were regarded as normal for gestational age according to national standards. Four of the affected fetuses were born dead. Infant birth weight and gestational age at delivery are not known for the nine unaffected fetuses, which were delivered at regional hospitals.

\section{IGF and IGFBP RIA}

IGF-I. The median of the serum IGF-I concentrations in human fetuses of 19 to 35 wk gestation was $53 \mu \mathrm{g} / \mathrm{L}$ (range, 20-107 $\mu \mathrm{g} / \mathrm{L}$ ). The IGF-I concentration increased significantly with gestational age $(r=0.52, p<$ 0.005 ) from a mean of $40 \mu \mathrm{g} / \mathrm{L}$ at $20 \mathrm{wk}$ to $75 \mu \mathrm{g} / \mathrm{L}$ at 35 wk with a predicted concentration of $90 \mu \mathrm{g} / \mathrm{L}$ at term (Fig. 1A). There was a strong positive correlation between log-transformed IGF-I and $\mathrm{Hb}(r=0.57, p<$ $0.001)$. Multiple regression analysis revealed that IGF-I correlated with gestational age and $\mathrm{Hb}$ with an $r$ value of $0.68(p<0.001)$ (Table 1). Multiple regression analysis demonstrated that the birth weights of affected fetuses were correlated with serum IGF-I concentrations at the time of cordocentesis $(r=0.54, p=0.05)$ when covariation with the gestational age at birth $(r=$ $0.88, p<0.001)$ and the gestational age at the time of cordocentesis $(r=0.39, p=\mathrm{NS})$ were excluded (combined $r=0.91, p<0.001$ ) (Table 1).

IGF-II. The median fetal serum IGF-II concentration was $236 \mu \mathrm{g} / \mathrm{L}$ (range, 135-367 $\mu \mathrm{g} / \mathrm{L}$ ). IGF-II levels increased slightly with gestational age $(r=0.36, p<0.05)$, 

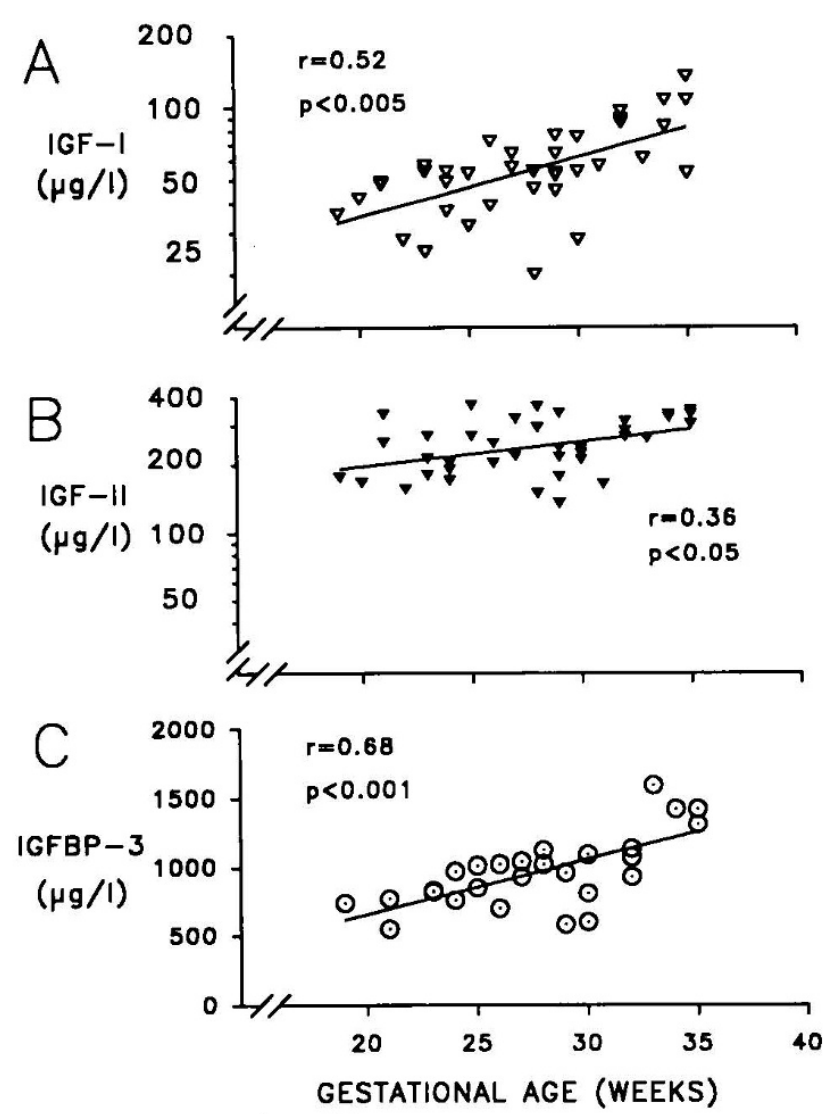

Figure 1. The correlation of immunoreactive serum IGF-I $(A)$, IGF-II $(B)$, and IGFBP-3 $(C)$ concentrations with gestational age of human fetuses of rhesus-isoimmunized pregnancies. Immunoreactive peptides were determined by specific RIA in fetal serum obtained from the umbilical cord in utero. The correlation coefficients were $r=0.52(p<0.005$, $n=34), r=0.36(p<0.05, n=34)$, and $r=0.68(p<0.001, n=27)$ between gestational age and IGF-I, IGF-II and IGFBP-3, respectively.

with the mean IGF-II concentration rising from $200 \mu \mathrm{g} / \mathrm{L}$ at $20 \mathrm{wk}$ to $275 \mu \mathrm{g} / \mathrm{L}$ at $35 \mathrm{wk}$ and with a predicted concentration of $310 \mu \mathrm{g} / \mathrm{L}$ at term (Fig. $1 B$ ). No correlation between IGF-II and $\mathrm{Hb}$ concentrations was displayed.
IGFBP-I. IGFBP-1 concentrations displayed large variability, with a median of $25 \mu \mathrm{g} / \mathrm{L}$ (range, $6-222 \mu \mathrm{g} / \mathrm{L}$ ). As shown in Figure 2A, IGFBP-1 was inversely correlated with the IGF-I concentration $(r=-0.53, n=33, p<0.005)$.

IGFBP-2. The median IGFBP-2 concentration was 640 $\mu \mathrm{g} / \mathrm{L}$ (range, $130-1530 \mu \mathrm{g} / \mathrm{L}$ ). IGFBP-2 was inversely correlated to the log-transformed IGF-I concentration $(r$ $=-0.56, n=26, p<0.005$ ) (Fig. 2B). A significant inverse correlation between IGFBP-2 and $\mathrm{Hb}(p<0.05)$ was found by multiple regression analysis to be explained by the covariation of $\mathrm{Hb}$ and IGF-I.

IGFBP-3. The median IGFBP-3 concentration was 960 $\mu \mathrm{g} / \mathrm{L}$ (range, 550-1590 $\mu \mathrm{g} / \mathrm{L}$ ). IGFBP-3 increased with increasing gestational age of the fetus $(r=0.68, n=27, p<$ $0.001)$ from a mean of $800 \mu \mathrm{g} / \mathrm{L}$ at $20 \mathrm{wk}$ to about $1400 \mu \mathrm{g} / \mathrm{L}$ at $35 \mathrm{wk}$ of gestation (Fig. 1C). IGFBP-3 was correlated with the log-transformed IGF-I concentration $(p<0.05)$. However, this relationship was found by multiple regression analysis to be due to covariation between IGF-I and gestational age. IGFBP-3 was not correlated with log-transformed IGF-II concentrations (Table 1).

\section{Stoichiometry of IGF and IGFBP Concentrations}

Figure $2 C$ shows that the total molar concentration of IGF-I plus IGF-II was significantly correlated with the molar concentration of IGFBP-3 $(r=0.55, p<0.005)$. The median of the molar ratio between [IGF-I + IGF-II] and [IGFBP-3] was $1.5(0.8-2.8)$. The ratio between IGFBP-3 and IGFBP-2 concentrations averaged 1.4 and displayed a positive correlation with gestational age $(r=$ $0.70, p<0.001)$.

\section{Western Ligand Blot Analysis of IGFBP}

Western ligand blot analysis of fetal serum (Fig. 3) revealed IGFBP bands at $40 \mathrm{kD}$ and $38 \mathrm{kD}$ comigrating with recombinant human glycosylated IGFBP-3 (data not

Table 1. Correlations between serum concentrations of IGF-I and -II and IGFBP-1, -2, and -3 and various other parameters*

\begin{tabular}{|c|c|c|c|c|c|c|}
\hline $\begin{array}{c}\text { Dependent } \\
\text { variable }\end{array}$ & $\log$ IGF-I & $\log$ IGF-II & IGFBP-3 & IGFBP-2 & IGFBP-1 & $\begin{array}{c}\text { Birth } \\
\text { weight }\end{array}$ \\
\hline $\begin{array}{l}\text { Linear } \\
\quad \text { regressions } v s\end{array}$ & $\begin{array}{l}\text { Gest age: } \\
\quad r=0.52 \dagger \\
\text { HB: } \\
r=0.57 \S\end{array}$ & $\begin{array}{l}\text { Gest age: } \\
\quad r=0.36 \ddagger \\
\mathrm{Hb}: \\
r=0.17 \|\end{array}$ & $\begin{array}{l}\text { Gest age: } \\
\quad r=0.68 \S \\
\text { IGF-I + IGFII } 1: \\
r=0.55 \dagger\end{array}$ & $\begin{array}{c}\log \text { IGF-I: } \\
r=0.56 \dagger \\
\text { HB: } \\
r=-0.38 \ddagger\end{array}$ & $\begin{array}{c}\log \text { IGF-1: } \\
r=0.53 \dagger\end{array}$ & \\
\hline \multirow[t]{4}{*}{$\begin{array}{l}\text { Multiple } \\
\quad \text { regression } v s\end{array}$} & $\begin{array}{l}\text { Gest age: } \\
\quad r=0.52^{* *}\end{array}$ & & $\begin{array}{l}\text { Gest age: } \\
\quad r=0.68 \S\end{array}$ & $\begin{array}{c}\log \text { IGF-I: } \\
\quad r=0.56 \ddagger\end{array}$ & & $\begin{array}{l}\log \text { IGF-I: } \\
r=0.54 \ddagger\end{array}$ \\
\hline & $\begin{array}{l}\mathrm{Hb}: \\
\quad r=0.57 \dagger\end{array}$ & $\begin{array}{l}\text { IGF-I: } \\
\quad r=0.39 \|\end{array}$ & $\begin{array}{l}\text { HB: } \\
\qquad r=-0.38 \uparrow\end{array}$ & & $\begin{array}{l}\text { Gest age: } \\
\quad r=0.88 \S\end{array}$ & \\
\hline & $\begin{array}{l}\text { Combined: } r \\
=0.68 \S\end{array}$ & & $\begin{array}{l}\text { IGF-II: } \\
\quad r=0.31 \|\end{array}$ & $\begin{array}{l}\text { Combined: } \\
r=0.51 \ddagger\end{array}$ & $\begin{array}{l}\text { Gest age: } \\
\quad r=0.39 \|\end{array}$ & \\
\hline & & & $\begin{array}{c}\text { Combined: } \\
r=6.63 \S\end{array}$ & & & $\begin{array}{r}\text { Combined: } \\
r=0.91 \S\end{array}$ \\
\hline
\end{tabular}

* Gest age, gestational age; Gest age ${ }_{\mathrm{B}}$, gestational age at birth.

$\dagger p<0.005$.

$\ddagger p<0.05$.

$\S p<0.001$.

$\| p=$ NS.

q Molar concentrations.

${ }^{* *} p<0.01$. 


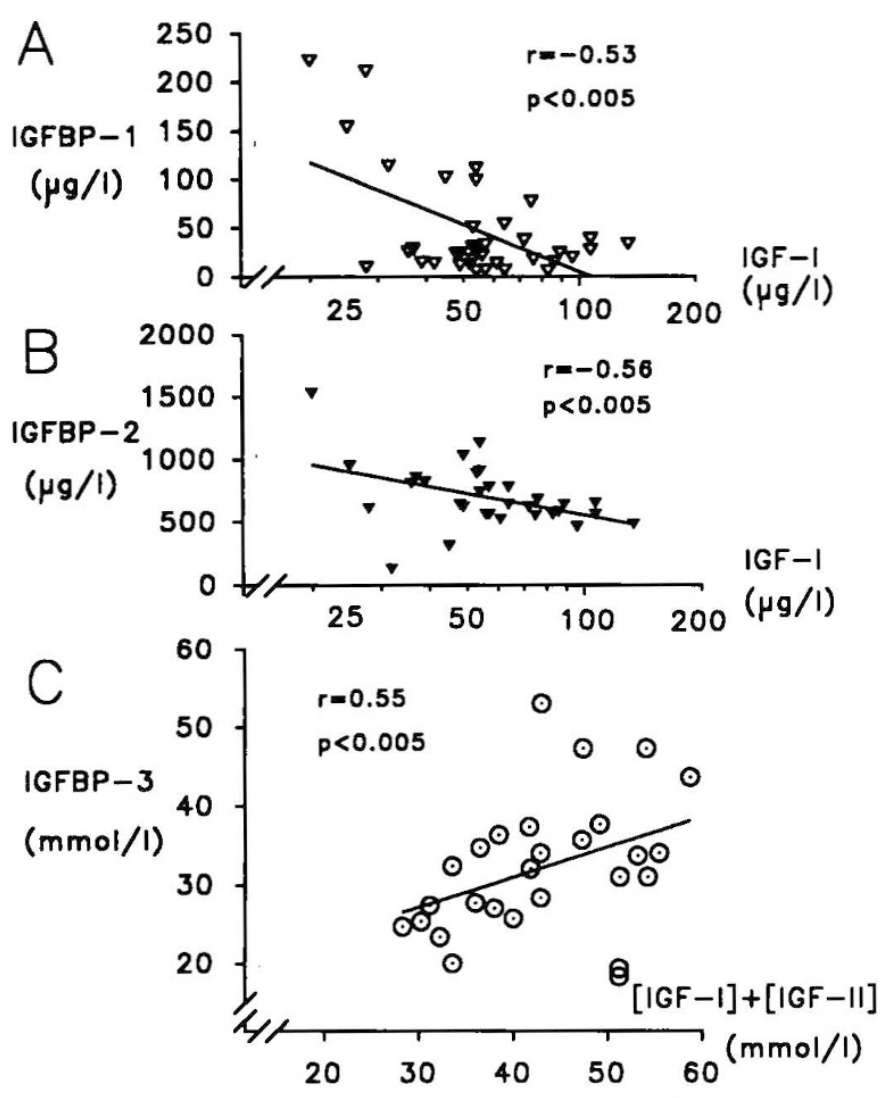

Figure 2. The correlation of immunoreactive IGFBP-1 $(A)$ and IGFBP-2 $(B)$ concentrations with the IGF-I concentration and the correlation of the molar concentration of IGFBP-3 with the total molar concentration of IGF-I and IGF-II $(C)$ in serum from human fetuses of rhesus-isoimmunized pregnancies. Immunoreactive peptides were determined by specific RIA in fetal serum obtained from the umbilical cord in utero. The correlation coefficients were $r=-0.53(p<0.005$, $n=33)$ and $r=-0.56(p<0.005, n=26)$ between IGF-I and IGFBP-1 and IGFBP-2, respectively. The correlation coefficient between [IGFBP-3] and [IGF-I] + [IGF-II] was $r=0.55(p<0.005)$.

shown) and precipitated by anti-IGFBP-3 antibody ( $\alpha$ IGFBP-3-g1; Fig. 4); at $26 \mathrm{kD}$, comigrating with recombinant human IGFBP-1 (not shown); and at $24 \mathrm{kD}$, presumably representing IGFBP-4 (37). In addition, the 31to $28-\mathrm{kD}$ molecular mass range displayed at least two bands, not completely resolved, of which the upper band comigrated with recombinant human IGFBP-2 and was precipitated by $\alpha$-HEC antibody as was the $40-$ to $38-\mathrm{kD}$ doublet ( $\alpha$-HEC antibody has a weak affinity for IGFBP-3) (Fig. 4). The predominant [ ${ }^{125}$ I]IGF binding capacity in fetal serum was displayed by IGFBP-3, with a mean $( \pm$ SEM) absorbance level of $7.2 \pm 9.0 \mathrm{AU} \times \mathrm{mm}$ $(n=31)$. The 31 - to $28-\mathrm{kD}$ band, partially attributable to IGFBP-2, had a mean absorbance level of $3.26 \pm 2.60 \mathrm{AU}$ $x \mathrm{~mm}$, whereas the $26-\mathrm{kD}$ and $24-\mathrm{kD}$ bands had mean absorbance levels of $0.50 \pm 0.54$ and $0.38 \pm 0.21 \mathrm{AU} \times$ $\mathrm{mm}$, respectively. IGFBP-3 determined by Western ligand blotting correlated significantly with immunoassayable IGFBP-3 $(r=0.63, p<0.005)$ and was inversely correlated with the IGFBP-3 protease activity $(r=$ $-0.57, p<0.005$ ) (see below). Multiple regression analysis displayed a combined correlation coefficient of $r=$
0.77 , with $p<0.001$ ( $r=0.55$ and $p<0.005$ for IGFBP-3 by Western ligand blotting and by RIA; $r=-0.43$ and $p$ $<0.01$ for IGFBP-3 by Western ligand blotting and IGFBP-3 protease activity). As seen in Figure 3, one fetal serum (the third lane at $29 \mathrm{wk}$ gestation) displayed very faint bands, suggesting the presence of proteolytic activity, either intrinsic or from contaminating amniotic fluid. This serum displayed the highest proteolytic activity of all the fetal serum samples (156\% of that of a control adult serum pool; see below). In contrast, Western ligand blot determinations of the $31-\mathrm{kD}$ band, attributable to IGFBP-2, and the 26-kD IGFBP-1 band did not display significant correlations with immunoassayable IGFBP-2 and IGFBP-1, respectively. The 24-kD IGFBP-4 band did not correlate significantly with any of the parameters reported here.

IGFBP-3 protease activity. To determine whether increased IGFBP-3 proteolytic activity in maternal serum and amniotic fluid also affects the fetal compartment, the IGFBP-3 proteolytic activity in fetal serum was determined. Figure 5 shows a representative protease assay of 19- to 24-wk gestation human fetal sera. Densitometric analysis of all fetal sera demonstrated a median IGFBP-3 protease activity of $96 \%$ (range, 21-156\%) of a control serum pool from healthy adults, which was given an arbitrary value of $100 \%$. Human pregnant serum, by comparison, displayed an IGFBP-3 protease activity of $256 \%$ of the control serum pool (median of four determinations).

\section{DISCUSSION}

Serum concentrations of immunoreactive IGF-I increased exponentially with gestational age in human fetuses of 19 to $35 \mathrm{wk}$ gestation, whereas IGF-II displayed only a slight increase. Our results are in agreement with the changes in IGF-I and IGF-II concentrations with gestational age reported in serum obtained in utero from normal human fetuses of 15-23 (6) and 20-37 wk gestation (7), although the absolute concentrations in the latter report are somewhat higher. The predicted serum IGF-I and IGF-II concentrations at term are in accordance with those determined in healthy newborns, using the same assays (26). These notions are important, because they may suggest that there was no major effect on the IGFIGFBP axis in fetuses affected by rhesus isoimmunization in the present study.

The low serum IGF-I levels during rapid fetal growth may seem to challenge the role of IGF-I as an endocrine growth factor. However, IGF-I bioavailability in fetal serum is likely to be increased. In fetal serum, the mean IGFBP-3 concentration was 4 -fold decreased relative to adult concentrations and the mean molar ratio of [IGF-I] $+[$ IGF-II] to [IGFBP-3] was $1.5: 1,50 \%$ higher than that reported in adults $(33,38)$. Serum IGFBP-2 concentrations, on the other hand, were 3-fold elevated. Rapid pubertal growth is also associated with an increased IGF to IGFBP-3 ratio (39). Because less IGF-I is bound by IGFBP-3, which has a 10-fold higher affinity for IGF-I 

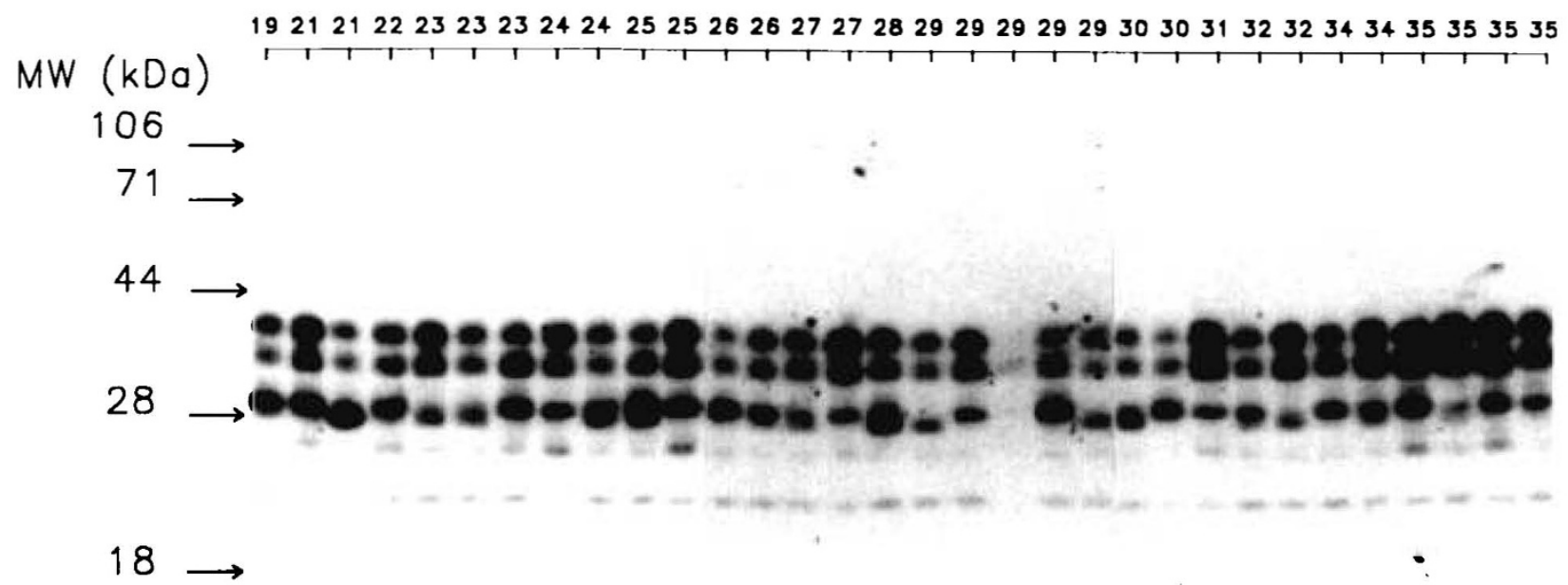

Figure 3. Western ligand blot analysis of serum IGFBP in 19- to 35-wk gestation human fetuses of rhesus-isoimmunized pregnancies. Fetal serum was obtained from the umbilical cord in utero and processed by SDS-PAGE under nonreducing conditions, electroblotted to nitrocellulose, and probed with a mixture of ${ }^{125}$ I-labeled IGF-I and IGF-II (see Methods). For the designation of bands to specific IGFBP, see Figure 4 and Methods. Laser densitometric scanning was used to quantitate the bands.

than does IGFBP-2 (40), potentially less IGF-I will be "trapped" in the ternary complex and more IGF-I will be bound by IGFBP-2 in the binary complex. Therefore, IGF-I availability is likely to be increased, given that the IGF-I half-life in the ternary complex is $15 \mathrm{~h}$, compared with $0.5 \mathrm{~h}$ in the binary complex [based on data from adult human serum (17)]. This conclusion is in agreement with previous studies showing that the distribution of IGF between the binary and ternary complexes is altered in human $(7,41)$ and sheep fetal serum $(42)$, with an

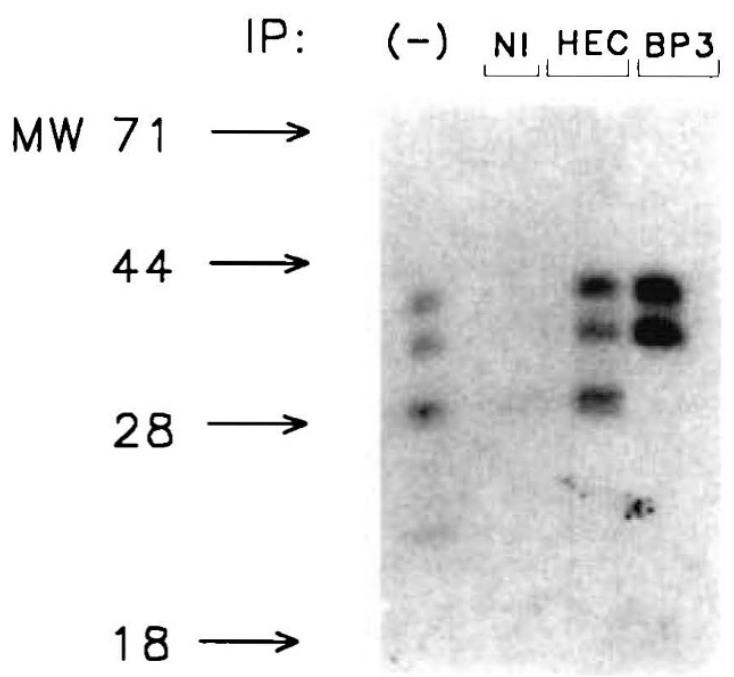

Figure 4. Western ligand blotting of fetal serum without $(-)$ or with prior immunoprecipitation with nonimmune rabbit serum $(N I)$, antiIGFBP-2 antibody; $\alpha$-HEC $(H E C)$, which also has a low affinity for IGFBP-3; or anti-IGFBP-3 antibody, $\alpha$-IGFBP-3 g-1 (BP3). Serum (5 $\mu \mathrm{L})$ was incubated with $5 \mu \mathrm{L}$ of the undiluted antiserum in a total volume of $50 \mu \mathrm{L}$ of SAC 1 buffer overnight at $4^{\circ} \mathrm{C}$. After precipitation of immune complexes with Pansorbin and subsequent washes, IGFBP were released by boiling in nonreducing SDS sample buffer for $5 \mathrm{~min}$. The supernatant was processed by Western ligand blotting as described in Figure 3 and Methods. increased fraction of total IGF in the binary complex. The increase in IGF-I availability may be even more pronounced in the early gestation human fetus because serum IGFBP-3 concentrations as well as the IGFBP3:IGFBP-2 ratio increase with gestational age, as also previously reported (43).

In addition to functioning as short- and longer-term storage for IGF-I, IGFBP may act as transcapillary carriers of IGF-I, regulating IGF-I availability and seques-

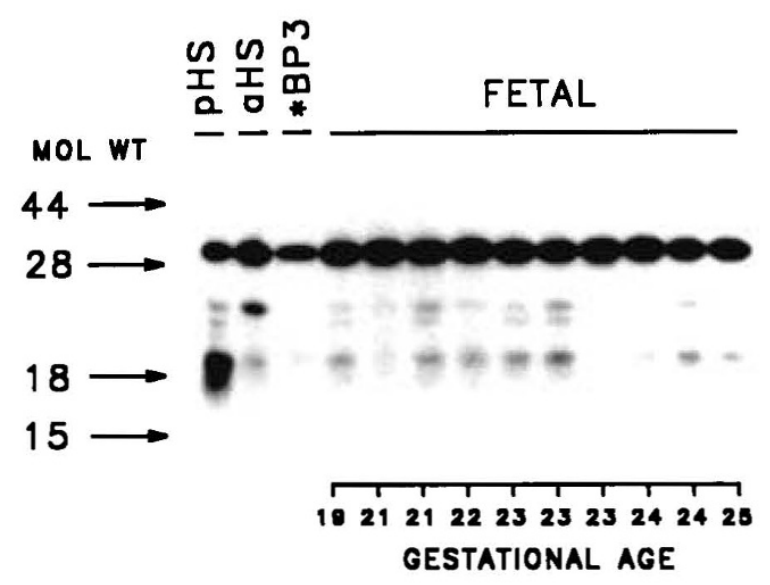

Figure 5. IGFBP-3 protease activity in fetal serum determined by IGFBP-3 protease assay. A representative gel of fetal serum from 19- to 24-wk gestation human fetuses of rhesus-isoimmunized pregnancies is shown. Briefly, $2 \mu \mathrm{L}$ of serum were incubated with nonglycosylated $\left.{ }^{125} \mathrm{I}\right]-$ IGFBP-3 $(30000 \mathrm{cpm})$ for $5 \mathrm{~h}$ at $37^{\circ} \mathrm{C}$ and then processed by SDS-PAGE. Gels were dried and autoradiographed. The IGFBP-3 protease activity was defined as the absorbance of $\left[{ }^{125}\right.$ I]IGFBP-3 fragments with molecular mass less than $30 \mathrm{kD}$ (intact peptide). To correct for interassay variability, the protease activities in individual fetal serum samples were expressed as a percentage of the protease activity in a control pool of adult serum $(a H S)$, which was given an arbitrary value of $100 \%$. $\left[{ }^{125} \mathrm{I}\right]$ IGFBP-3 incubated with pregnancy human serum $(p H S)$ or assay buffer $\left({ }^{*} B P 3\right)$ was processed in parallel for comparison. Molecular mass markers in $\mathrm{kD}$ are shown on the left. 
tration in the tissues. IGFBP-1 has been suggested to act as such an IGF carrier, and this process may be increased by insulin both in rats $(18,19)$ and in humans $(44)$. IGF-I and human IGFBP-1 infused in equi-molar ratios to rats was not as potent as IGF-I alone, and human IGFBP-1 infused alone (reaching 50-fold the normal rat IGFBP-1 concentration) may block the actions of endogenous IGF (45). It is not clear from that study, however, whether normal physiologic concentrations of rat IGFBP-1 may play a role as a transcapillary carrier of IGF-I. However, it is tempting to hypothesize that increased IGFBP-1 concentrations reported in serum from IUGR newborns $(12,26,27)$ may signify an accumulation of IGFBP-1 in the circulation, resulting in decreased transport of IGF to target tissues and decreased growth. Similarly, IGFBP-1 concentrations in cord serum from term newborns have been reported to be high, although variable $(12,25-27)$, which may suggest that IGF-I transport and availability are decreased immediately after birth in accordance with the temporary lack of growth. Importantly, in the rapidly growing human fetus in utero, serum IGFBP-1 concentrations, which have not previously been measured by RIA, were not generally increased. Serum IGFBP-1 expression is inhibited by insulin postnatally (46), and IGFBP-1 concentrations are increased rapidly by shortterm fasting (47-49). Whether factors like low maternal nutritional intake before delivery and restricted placental blood and nutrient flow during delivery and stress (50) may result in increased serum IGFBP-1 in the newborn is not known. IGFBP-1 and IGFBP-2 were inversely correlated with the fetal serum IGF-I concentration. These correlations are expected from the findings of increased serum IGFBP-1 and IGFBP-2 levels by Western ligand blotting and decreased IGF-I in IUGR newborns $(21,27$, 43). IGF-I has been reported to inhibit IGFBP-1 production in Hep G-2 cells (51), which, similar to the fetal liver but unlike the adult liver, display high expression of the type 1 IGF receptor $(2,52)$. Because the fetal human liver is the major production site for IGFBP-1 and IGFBP-2 $(14,15)$, IGF-I may regulate their expression in the human fetus.

In contrast to term pregnancy serum and amniotic fluid (21-23), increased IGFBP-3 protease activity could not be demonstrated in human fetal serum. Thus, the human fetal compartment is protected from the IGFBP-3 serum protease(s) [or contains the appropriate protease inhibitor(s)], suggesting that IGFBP-3 protease(s) is not involved in regulating IGF-I availability in human fetal serum. Although not increased, IGFBP-3 proteolysis did interfere with IGFBP-3 determinations by Western ligand blotting, as demonstrated by the inverse correlation between IGFBP-3 proteolytic activity and IGFBP-3 levels determined by Western ligand blotting. The loss of IGFBP-3 detection by Western ligand blotting has been explained by decreased affinity of proteolytic IGFBP-3 fragments for radiolabeled IGF (53). However, the interference was moderate because IGFBP-3 levels by RIA and Western ligand blotting remained significantly corre- lated. Furthermore, the lack of correlations between RIA and Western ligand blot determinations of IGFBP-1 and IGFBP-2 may be explained by the small quantities of IGFBP-1 in serum and the lack of resolution of the IGFBP-2 band from other IGFBP bands in the $30-\mathrm{kD}$ molecular mass range (i.e. glycosylated IGFBP-4, IGFBP-5, or IGFBP-6). These findings emphasize the problems of quantitation by Western ligand blotting previously demonstrated by others $(23,24)$.

It is debatable whether anemic fetuses, affected by rhesus isoimmunization of the mothers, have a restricted growth rate. In a limited number of cases of rhesus isoimmunization, it was reported that a fetal $\mathrm{Hb}$ concentration less than $30 \%$ of normal was associated with a decreased fetal growth rate (54). However, these findings could not be confirmed in less-affected fetuses (55). In the present study, which included five fetuses with $\mathrm{Hb}$ less than $30 \%$ of normal, fetal sizes at birth were regarded as normal for gestational age, perhaps because the affected fetuses were treated with blood transfusions in utero. There was a strong positive correlation between IGF-I and $\mathrm{Hb}$, which suggests that erythroblastosis and anemia are associated with decreased circulating IGF-I levels, even in less severe cases. Furthermore, there was a significant correlation between the birth weights and fetal serum IGF-I levels, regardless of when they were measured. Correlations between fetal size and serum IGF-I concentrations in utero and in the newborn have been previously reported $(6,7,9-12)$. Therefore, it could be speculated that impaired growth in anemic human fetuses at least partially results from low serum IGF-I levels. In the present study, neither IGFBP-1 nor IGFBP-3 was significantly correlated with $\mathrm{Hb}$, and the correlation between IGFBP-3 and $\mathrm{Hb}$ was due to covariation between $\mathrm{Hb}$ and gestational age, as revealed by multiple regression analysis.

In conclusion, increased IGF-I bioavailability in human fetal serum is suggested by the increased quantitative importance of IGFBP-2, which, in contrast to IGFBP-3, does not form a long-lived ternary complex with IGF-I and ALS. Furthermore, fetal serum IGFBP-1 concentrations were not elevated as previously reported in newborn serum, which may be of importance for the normal delivery of IGF-I to the tissues. Although the fetal circulation is not affected by increased IGFBP-3 proteolysis, as previously demonstrated in pregnancy serum and amniotic fluid, additional studies are needed to assess ternary complex formation. Finally, the present study points out some problems associated with the detection of IGFBP by Western ligand blotting and stresses the importance of IGFBP determinations by specific, quantitative techniques in fetal serum.

Acknowledgment. The authors thank Dr. Farah Abdul Jabbar, MRCOG, Executive Director, King Faisal Specialist Hospital, Riyadh, Saudi Arabia, for his support of this research program and the care of patients whose pregnancies were complicated by rhesus isoimmunization. 


\section{REFERENCES}

1. Han VKM, Hill DJ 1992 The involvement of insulin-like growth factors in embryonic and fetal development. In: Schofield PN (ed) The Insulin-Like Growth Factors: Structure and Biological Functions. Oxford University Press, Oxford, UK, pp 178-205

2. Sara RV, Hall K, Misaki M, Fryklund L, Christensen N, Wetterberg L 1983 Ontogenesis of somatomedin and insulin receptors in the human fetus. J Clin Invest 71:1084-1094

3. Han VK, Lund PK, Lee DC, D'Ercole AJ 1988 Expression of somatomedin/ insulin-like growth factor messenger ribonucleic acids in the human fetus: identification, characterization and tissue distribution. J Clin Endocrinol Metab 66:422-429

4. Han VKM, D'Ercole AJ, Lund PK 1987 Cellular localization of somatomedin (insulin-like growth factor) messenger RNA in the human fetus. Science 236:193-197

5. Grizzard JD, D'Ercole AJ, Wilkins JR, Moats-Staats BM, Wiliams RW 1984 Affinity-labeled somatomedin-C receptors and binding proteins from human fetus. J Clin Endocrinol Metab 58:535-543

6. Ashton IK, Zapf J, Einschenk I, MacKenzie IZ 1985 Insulin-like growth factors (IGF) I and II in human foetal plasma and relationship to gestational age and foetal size during midpregnancy. Acta Endocrinol (Copenh) 110:558563

7. Lasserre C, Hardouin S, Daffos F, Forestier F, Frankenne F, Binoux M 1991 Serum insulin-like growth factors and insulin-like growth factor binding proteins in the human fetus. Relationship with growth in normal subjects and in subjects with intrauterine growth retardation. Pediatr Res 29:219-225

8. Millner RDG, Hill DJ 1987 Interaction between endocrine and paracrine peptides in prenatal growth control. Eur J Pediatr 146:113-122

9. Zapf J, Walter H, Froesch ER 1981 Radioimmunological determinations of insulin-like growth factors I and II in normal subjects and in patients with growth disorders and extrapancreatic tumours. J Clin Invest 68:1321-1330

10. Bennett A, Wilson DM, Liu F, Nagashima R, Rosenfeld RG, Hintz RL 1983 Levels of insulin-like growth factors I and II in human cord blood. J Clin Endocrinol Metab 57:609-612

11. Gluckman PD, Johnson-Barrett JJ, Butler JH, Edgar BW, Gunn TR 1983 Studies of insulin-like growth factor-I and -II by specific radioligand assays in umbilical cord blood. Clin Endocrinol 19:405-413

12. Verhaeghe J, Van Bree R, Van Herck E, Laureys J, Bouillon R, Van Assche FA 1993 C-peptide, insulin-like growth factors-I and -II, and IGF-binding protein 1 in umbilical cord serum: correlations with birthweight. Am J Obstet Gynecol 169:89-97

13. Lamson G, Giudice LC, Rosenfeld RG 1991 Insulin-like growth factor binding proteins: structural and molecular relationships. Growth Factors 5:19-28

14. Hill DJ, Han VKM, Clemmons DR, Camacho-Hubner C, Wang JF 1990 Expression, distribution, release and biological action of insulin-like growth factor binding proteins during developement. In: Drop SLS, Hintz RL (eds) Insulin-Like Growth Factor Binding Proteins. Excerpta Medical International Congress Series. Elsevier, Amsterdam, pp 55-61

15. Delhanty PJD, Hill DJ, Han VKM 1992 Insulin-like growth factor binding protein (IGFBP) mRNAs in the human fetus: expression, tissue distribution and cellular localization. 73th Annual Meeting of the American Endocrine Society, San Antonio, TX, p 292 (abstr 963)

16. Delhanty PJ, Hill DJ, Shimasaki S, Han VK 1993 Insulin-like growth factor binding protein $-4,-5$ and -6 mRNAs in the human fetus: localization to sites of growth and differentiation? Growth Regul 3:8-11

17. Guler H-P, Zapf J, Schmid C, Froesch J 1989 Insulin-like growth factor I and II in healthy man. Estimations of half-lives and production rates. Acta Endocrinol (Copenh) 121:753-758

18. Bar RS, Boes M, Clemmons DR, Busby WH, Sandra A, Dake BL, Booth BA 1990 Insulin differentially alters transcapillary movement of intravascular IGFBP-1, IGFBP-2 and endothelial cell IGF-binding proteins in the rat heart. Endocrinology 127:496-499

19. Bar RS, Boes M, Dake BL, Sandra A, Bayne M, Cascieri M, Booth BA 1990 Tissue localization of perfused endothelial cell IGF binding protein is markedly altered by association with IGF-I. Endocrinology 127:3243-3245

20. Baxter RC 1988 Characterization of the acid-labile subunit of the growth hormone-dependent insulin-like growth factor binding protein complex. J Clin Endocrinol Metab 67:265-272

21. Giudice LC, Farrell EM, Pham HM, Lamson G, Rosenfeld RG 1990 Insulinlike growth factor binding proteins in maternal serum throughout gestation and in the puerperium: effects of a pregnancy-associated serum protease activity. J Clin Endocrinol Metab 71:806-816

22. Hossenlopp P, Sergovia B, Lassarre C, Roghani M, Bredon M, Binoux M 1990 Evidence of enzymatic degradation of insulin-like growth factor-binding proteins in the $150 \mathrm{~K}$ complex during pregnancy. J Clin Endocrinol Metab 71:797-805

23. Gargosky SE, Pham HM, Wilson KF, Liu F, Giudice LC, Rosenfeld RG 1992 Measurements and characterization of insulin-like growth factor binding protein 3 in human biological fluids: discrepancies between radioimmunoassay and ligand blotting. Endocrinology 131:3051-3060

24. Bang P, Brismar K, Rosenfeld RG 1994 Increased proteolysis of insulin-like growth factor binding protein (IGFBP)-3 in NIDDM serum, with elevation of a $29 \mathrm{kDa}$ glycosylated IGFBP-3 fragment contained in the ternary complex. J Clin Endocrinol Metab 78:1119-1127
25. Hall K, Hansson U, Lundin G, Luthman M, Persson B, Povóa G, Stangenberg M, Öfverholm U 1986 Serum levels of somatomedins and somatomedin binding protein in pregnant women with type I or gestational diabetes and their infants. J Clin Endocrinol Metab 63:1300-1306

26. Bernardini S, Spadoni GL, Pòvoa G, Boschermi B, Hall K 1992 Plasma levels of insulin-like growth factor binding protein-1, and growth hormone binding protein activity from birth to third month of life. Acta Endocrinol (Copenh) 127:313-318

27. Wang HS, Lim J, English J, Irvine L, Chard T 1991 The concentration of insulin-like growth factor-I (IGF-I) and insulin-like growth factor binding protein-1 (IGFBP-1) in human umbilical cord serum at delivery: relation to fetal weight. J Endocrinol 129:459-464

28. Daffos F, Capella-Pavlovsky M, Forestie F 1985 Fetal blood sampling during pregnancy with use of a needle guided by ultrasound: a study of 606 consecutive cases. Am J Obstet Gynecol 153:655-662

29. Lamson G, Giudice LC, Rosenfeld RG 1991 A simple assay for proteolysis of IGFBP-3. J Clin Endocrinol Metab 72:1391-1393

30. Bang P, Eriksson U, Sara V, Wivall I-L, Hall K 1991 Comparison of acid ethanol extraction and acid gel filtration prior to IGF-I and IGF-II radioimmunoassays: improvement of determinations in acid ethanol extracts by the use of truncated IGF-I as radioligand. Acta Endocrinol (Copenh) 124:620-629

31. Póvoa G, Roovete A, Hall K 1984 Cross-reaction of serum somatomedin binding protein in a radioimmunoassay developed for somatomedin-binding protein isolated from human amniotic fluid. Acta Endocrinol (Copenh) 107:563-570

32. Schwander J, Mary JL 1993 The RIA for IGFBP-2 in man: a meagre catch? Growth Regul 3:104-108

33. Blum WF, Ranke MB, Kiezmann K, Gauggel E, Zeisel HJ, Bierich JR 1990 A specific radioimmunoassay for the growth hormone $(\mathrm{GH})$-dependent somatomedin-binding protein: its use for diagnosis of $\mathrm{GH}$ deficiency. $\mathrm{J}$ Clin Endocrinol Metab 70:1292-1298

34. Hossenlopp P, Seurin D, Segovia-Quinson B, Hardouin S, Binoux M 1986 Analysis of serum insulin-like growth factor binding proteins using Western ligand blotting: use of the method for titration of the binding proteins and competitive binding studies. Anal Biochem 154:138-143

35. Lamson G, Oh Y, Pham H, Giudice LC, Rosenfeld RG 1989 Expression of two insulin-like growth factor binding proteins in a human endometrial cance cell line: structural, immunological, and genetic characterization. J Clin Endocrinol Metab 69:852-859

36. Rodech $\mathrm{CH}$, Nicolini II 1988 Physiology of the midtrimester fetus. Br Med Bull 44:826-849

37. Roghani M, Lassarre C, Zapf J, Povoa G, Binoux M 1991 Two insulin-like growth factor (IGF) binding proteins are responsible for the selective affinity for IGF-II of cerebrospinal fluid binding proteins. J Clin Endocrinol Metab 73:658-666

38. Bang P, Degerblad M, Thorén M, Hall K 1993 Insulin-like growth factor (IGF) $I$ and II and IGF binding protein (IGFBP) 1,2 and 3 in serum from patients with Cushing's syndrome. Acta Endocrinol (Copenh) 128:397-404

39. Juul A, Hertel T, Main K, Nielsen CT, Krabbe S, Bang P, Hall K, Müller J, Skakkebaek NE 1993 The IGF-I/IGFBP-3 ratio increases during normal and precocious puberty: an index of free IGF-I? Fourth Joint LWPES/ESPE Meeting, San Francisco (abstr)

40. Oh Y, Müller HL, Lee D-Y, Fielder PJ, Rosenfeld RG 1993 Characterization of the affinities of insulin-like growth factor binding proteins 1-4 (IGFBPs 1-4) for IGF-I, IGF-II, IGF-I/insulin hybrid and IGF-I analogs. Endocrinology 132:1337-1344

41. Drop SLS, Kortleve DJ, Guyda HJ, Posner BI 1984 Immunoassay of somatomedin-binding protein from human amniotic fluid: levels in fetal, neonatal, and adult sera. J Clin Endcrinol Metab 59:908-915

42. Gluckman PD, Butler JH, Comline R, Fowden A 1987 The effects of pancreatectomy on the plasma concentrations of insulin-like growth factors 1 and 2 in the sheep fetus. J Dev Physiol 9:79-88

43. Crystal RA, Giudice LC 1991 Insulin-like growth factor binding protein (IGFBP) profiles in human fetal cord sera: ontogeny during gestation and differences in newborns with intrauterine growth retardation (IUGR) and large for gestational age (LGA) newborns. In: Spencer EM (ed) Modern Concepts of Insulin-like Growth Factors. Elsevier, New York, pp 395-408

44. Brismar K, Fernqvist-Forbes E, Wahren J, Hall K 1994 The effects of insulin on the hepatic secretion of IGFBP-1 and IGF-I in humans. Growth Regul 4(suppl 1):91(abstr I170)

45. Lewitt MS, Denyer GS, Cooney GJ, Baxter RC 1991 Insulin-like growth factor-binding protein-1 modulates blood glucose levels. Endocrinology 129:2254-2256

46. Brismar K, Gutniak M, Povoa G, Werner S, Hall K 1988 Insulin regulates the $35 \mathrm{kDa}$ binding protein in patients with diabetes mellitus. J Endocrinol Invest 11:599-602

47. Busby WH, Snyder DK, Clemmons DR 1988 Radioimmunoassay of a 26000 dalton plasma insulin-like growth factor-binding protein: control by nutritional variables. J Clin Endocrinol Metab 67:1225-1230

48. Yeoh SI, Baxter RC 1988 Metabolic regulation of the growth hormone independent insulin-like growth factor binding protein in human plasma. Acta Endocrinol (Copenh) 119:465-472

49. Bang P, Brismar K, Rosenfeld RG, Hall K 1994 Fasting affects serum insulin-like growth factors (IGFs) and IGF binding proteins differently in patients with NIDDM versus non-obese and obese, weight matched healthy subjects. J Clin Endocrinol Metab 78:960-967 
50. Fernqvist-Forbes, Wahren J, Hilding A, Brismar K 1994 Circulating epinephrine stimulates the secretion of IGFBP-1 in humans. Growth Regul 4(suppl 1):92(abstr 1175)

51. Lindgren BF, Isaksson M, Stern I, Hall K 1993 Insulin-like growth factor binding protein-1 from Hep G2 cells is potently inhibited by truncated IGF.I analogue des(1-3)IGF-I. Acta Endocrinol (Copenh) 128:81-87

52. Chernausek SD, Beach DC, Banach W, Sperling MA 1987 Characteristics of hepatic receptors for somatomedin-C/insulin-like growth factor 1 and insulin in the developing human. J Clin Endocrinol Metab 64:737-743
53. Suikkari A-M, Baxter RC 1991 Insulin-like growth factor (IGF) binding protein-3 in pregnancy serum binds native IGF-I but not iodo-IGF-I. J Clin Endocrinol Metab 73:1377-1379

54. Westgren M, Selbing A, Stangenberg M 1989 Fetal growth and fetal glucose and C-peptide levels in relation to the degree of anemia in fetuses affected by rhesus isoimmunization. Acta Obstet Gynecol Scand 68:309-311

55. Utter GO, Socol ML, Dooley SL, MacGregor SN, Millard DD 1990 Is intrauterine transfusion associated with diminished fetal growth? Am J Obstet Gynecol 163:1781-1784

\section{Announcement}

\section{Call for Abstracts}

The American Pediatric Society and The Society for Pediatric Research announce the abstract deadline for the 1995 Annual Meeting (May 8-11, 1995, San Diego Convention Center) has been set as January 3, 1995.

For further information, contact: APS/SPR Association Headquarters, 141 Northwest Point Blvd., P.O. Box 675, Elk Grove Village, IL 60009-0675, (708) 427-0205, Fax: (708) 427-1305. 